\title{
Advancing Point-of-Care (PoC) Testing Using Human Saliva as Liquid Biopsy
}

\author{
Rabia Sannam Khan ${ }^{1}$, Zohaib Khurshid ${ }^{2, *}$ (D) and Faris Yahya Ibrahim Asiri ${ }^{3}$ \\ 1 Department of Oral Pathology, College of Dentistry, Baqai University, Super Highway, P.O.Box: 2407, \\ Karachi 74600, Pakistan; rabia.sannam.khan@gmail.com \\ 2 Prosthodontics and Implantology, College of Dentistry, King Faisal University, Al-Ahsa 31982, Saudi Arabia \\ 3 Department of Preventive Dentistry, College of Dentistry, King Faisal University, Al-Ahsa 31982, \\ Saudi Arabia; fasiri@kfu.edu.sa \\ * Correspondence: drzohaibkhurshid@gmail.com; Tel.: +966-550-293-747
}

Received: 30 May 2017; Accepted: 30 June 2017; Published: 4 July 2017

\begin{abstract}
Salivary diagnostics is an emerging field for the encroachment of point of care technology (PoCT). The necessity of the development of point-of-care ( $\mathrm{PoC})$ technology, the potential of saliva, identification and validation of biomarkers through salivary diagnostic toolboxes, and a broad overview of emerging technologies is discussed in this review. Furthermore, novel advanced techniques incorporated in devices for the early detection and diagnosis of several oral and systemic diseases in a non-invasive, easily-monitored, less time consuming, and in a personalised way is explicated. The latest technology detection systems and clinical utilities of saliva as a liquid biopsy, electric field-induced release and measurement (EFIRM), biosensors, smartphone technology, microfluidics, paper-based technology, and how their futuristic perspectives can improve salivary diagnostics and reduce hospital stays by replacing it with chairside screening is also highlighted.
\end{abstract}

Keywords: saliva; diagnostic toolboxes; biomarkers; the point of care; diseases

\section{Introduction}

Laboratory testing remains the dominant mainstay for analytical processes of a large number of samples involving the disciplines of biochemistry, haematology, microbiology, anatomical pathology, and much more [1]. Due to the limitations and pressure on healthcare budgets faced by a very large number of countries, primary care is best suited for the world to reduce expenses instead of secondary and tertiary hospitals. Poverty, chronic disease, infections lead to significant problems in developing the world, and adequate diagnostic testing turns out to be difficult to meet the needs. Hence, consequently, initiatives in making solid models using point-of-care technology (PoCT) came into existence [2].

\subsection{Paradigm Shift from Central Laboratory $(C L)$ to Point-of-Care}

A self-monitoring blood glucose meter, coagulation (INR), and pregnancy testing kits using urine samples are well-known examples of PoCT and has become over-the-counter products to be sold in the market. Saliva is predicted to be a substitute for blood, collected non-invasively for the diagnosis of oral and systemic diseases. Thus, PoCT replaces the specialist testing centres by using the samples other than blood and urine [3]. For the development of PoCT devices, minimum risk of infection with no mental and physical pain is of utmost importance to consider, in addition to automation, integration, multiplexed detection ability, quick analysis, small sample size, and minimal training as the primary goals of modern medicine [4]. With the advent of the struggle in the growing potential of developing PoCT, the World Health Organization (WHO) provided guidelines which had 
the features for designing devices, known as the ASSURED criteria, which indicated that devices had to be affordable, sensitive, specific, user-friendly, rapid and robust, with no complex equipment, and be delivered to end users efficiently.

The precision to central lab testing is being facilitated by the use of biomarkers and saliva is a viable biofluid for diagnostic applications. The human saliva revolution in medical and dental sciences through its property as a "mirror of body health" in the last decade brought many disease detections through its compositional changes in disease conditions [5]. Human oral cavity consists of different sources, such as salivary glands (major and minor), gingival crevicular fluid (GCF), microbes, and oral epithelial sheds for the production of whole mouth fluid (WMF) [6-12]. This fluid is $99 \%$ water, but $1 \%$ consists of DNA, mRNA, microRNA, proteins, metabolites, and microbiota which are utilised as a diagnostic fluid for disease analysis and even for forensic analysis [13,14]. In this particular review, we present the current knowledge of saliva, diagnostic toolboxes, how PoC technology works, developed PoC devices for detection of various diseases, and the future prospects of utilising saliva as a diagnostic tool.

\subsection{Saliva in the Diagnosis of Oral and Systemic Diseases}

Saliva is a complex fluid containing various enzymes, electrolytes, proteins, nucleic acids, antimicrobial constituents, hormones, cytokines, and antibodies. Its composition virtually reflects the entire state of health and disease in a body and it has the potential of being a diagnostic medium for a broad range of diseases [15,16], such as in the detection of periodontal diseases, caries risk assessments, breast cancer, oral cancers, salivary gland diseases, HIV, and much more [16]. However, the effects of alteration in the salivary composition are seen in the lipid profile of cystic fibrosis patients, which is markedly changed in comparison to healthy subjects [17]. The submandibular gland saliva of cystic fibrosis patients contains $66 \%$ more lipids per $100 \mathrm{~mL}$ of saliva than that of a healthy subject. The salivary fatty acid profile can be a good indicator for the early detection of tumorigenesis processes and cardiovascular diseases. The increase in production of salivary arachidonic acid, relevant for their eicosanoid production related to the tumorigenesis process and cardiovascular diseases, is influenced by dietary fat intake [18]. Figure 1 portrays alterations of biomarkers in various body organs in diseased states through which saliva can detect a variety of oral and systemic diseases.

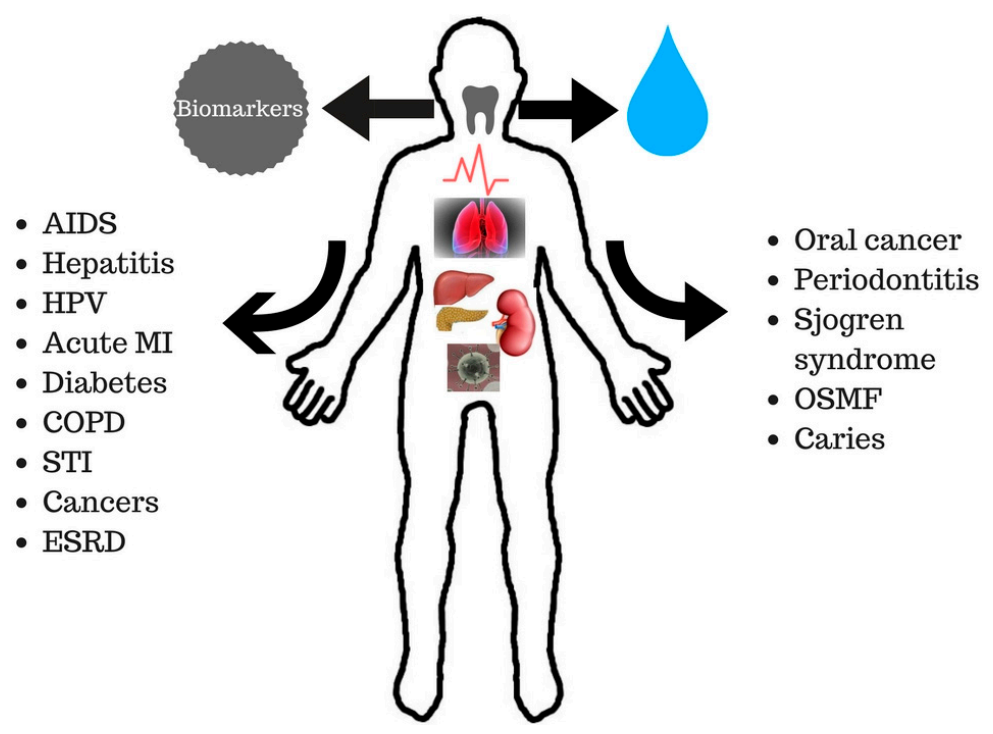

Figure 1. Depiction of the detection of various oral and systemic diseases through salivary biomarkers. Acquired Immuno Defeciency Syndrome (AIDS), Human Papilloma Virus (HPV), Myocardial infarction (MI), Chronic Obstructive Pulmonary Disease (COPD), Sexually Transmitted Infection (STI), End Stage Renal Failure (ESRD) and Oral Squamous Muccous Fibrosis (OSMF). 
Similarly, in Sjogren's syndrome (SS) the saliva flow is compromised in the patient due to ductal changes by lymphocytic infiltration and fibrosis of the salivary glands and the patient also suffers from the consequences of dental caries, infections dysphagia, and other oral pain [19]. The lipid profile of SS patients is twice higher than an average healthy person and elevated level of cytokines (IgA, IgG, interleukin-6, and prostaglandins-E2) and antibodies. Many salivary proteins were reported as biomarkers for SS diagnosis; for example, profilin [20], anhydrase-I [21], IL-4, IL-5 [22], MxA [23], and CXCL13 $[24,25]$. Human saliva has a proven diagnostic role in the detection of cardiovascular diseases, reported in studies examining whole mouth salivary biomarkers e.g., C-reactive proteins (CRP) [26], cardiac troponin (cTn) [27], creatine phosphokinase [28], and NT-ProBNP [29]. Diabetes is another common disease faced all around the world and developing rapidly due to dietary habits, genetic, and other systematic disease-related complications [30]. Due to its non-invasiveness, a cheap and easy sampling of saliva is attractive as a diagnostic fluid for diabetes analysis [31]. Previously reported studies concluded the different biomarkers for diabetes detection in early stages. A recently-reported study saw a marked alteration in levels of salivary glucose, amylase, calcium, and phosphorus in comparison to serum from diabetic and non-diabetic patients [32], as seen in Table 1 below.

The current review presents a broad overview on salivary diagnostics, the validation of biomarkers (diagnostic targets) through diagnostic toolboxes, discussion related to new biomarker-related PoC platforms, the latest emerging PoC technologies including highlights on biosensors, biological micro-electro-mechanical systems (BioMEMS), microfluidics/paper based technology, electric field-induced release and measurement (EFIRM), and smartphone-based biosensors their functions and clinical utility in medical field.

Table 1. Description of Point-of-care (PoC) devices for detection of diseases through specific salivary biomarkers.

\begin{tabular}{|c|c|c|c|}
\hline Salivary Biomarkers & Diseases/Conditions & Developed PoC & References \\
\hline A-amylase & $\begin{array}{l}\text { Clinical judgment for } \\
\text { stress-induced disease }\end{array}$ & $\begin{array}{l}\text { Salivary } \alpha \text {-Amylase (sAA) } \\
\text { biosensor system }\end{array}$ & [33] \\
\hline HIV & AIDS & Oraquick, tablet-based kiosks & {$[34,35]$} \\
\hline Hep C & Hepatitis & OraQuick & [36] \\
\hline $\mathrm{HPV}$ & $\begin{array}{l}\text { HPV-associated cancers, } \\
\text { sexually transmitted diseases }\end{array}$ & $\begin{array}{l}\text { simple fluorescent and colorimetric assay } \\
\text { that enables DNA and RNA detection }\end{array}$ & [37] \\
\hline Cortisol & Stress levels & Label-free chemiresistor immuno-sensor & [38] \\
\hline $\begin{array}{l}\text { Proteins (Dipeptidyl } \\
\text { peptidase etc.), } \\
\text { metabolites, DNA }\end{array}$ & Periodontitis & $\begin{array}{c}\text { Integrated Microfluidic Platform } \\
\text { for Oral Diagnostics (IMPOD), } \\
\text { lab-on-a-chip (LOC) }\end{array}$ & [39] \\
\hline $\begin{array}{l}\text { C-reactive protein, myoglobin, } \\
\text { and myeloperoxidase }\end{array}$ & Acute Myocardial Infarction & Luminex, lab-on-a-chip methods & {$[40]$} \\
\hline Cytokines & $\begin{array}{l}\text { Asthma and chronic obstructive } \\
\text { pulmonary disease (COPD) }\end{array}$ & $\begin{array}{l}\text { Fiber-optic microsphere-based } \\
\text { antibody array }\end{array}$ & [41] \\
\hline IL-8, IL-8mRNA & Oral Cancer & Electrochemical magneto biosensors & [42] \\
\hline $\begin{array}{c}\left.\text { ( } \mathrm{NO}_{2}-\text { and uric acid }\right) \\
\text { and pulmonary } \\
\text { inflammation biomarkers }\end{array}$ & $\begin{array}{l}\text { End-stage renal disease (ESRD), } \\
\text { asthma and chronic obstructive } \\
\text { pulmonary disease (COPD) patients }\end{array}$ & Optical fibre microarrays & [43] \\
\hline Salivary nicotine metabolites & Smoking/tobacco use & $\begin{array}{l}\text { Point of care test for salivary nicotine } \\
\text { metabolites }\end{array}$ & [44] \\
\hline Porphyromonas gingivalis & chronic periodontitis & P. gingivalis saliva kit & \\
\hline Gonorrhoea and chlamydia & $\begin{array}{l}\text { Sexually transmitted } \\
\text { infections (STIs) }\end{array}$ & Oral STI point-of-care (PoC) & {$[36]$} \\
\hline
\end{tabular}


Table 1. Cont.

\begin{tabular}{|c|c|c|c|}
\hline Salivary Biomarkers & Diseases/Conditions & Developed PoC & References \\
\hline $\begin{array}{l}\text { Salivary anti-Ro60 and } \\
\text { anti-Ro52 Antibody Profiles }\end{array}$ & Sjögren's Syndrome & $\begin{array}{l}\text { Luciferase Immunoprecipitation } \\
\text { Systems (LIPS) }\end{array}$ & [45] \\
\hline Salivary glucose & Diabetes & $\begin{array}{l}\text { Glucose monitoring using saliva } \\
\text { nanostructured biosensor }\end{array}$ & {$[46,47]$} \\
\hline $\begin{array}{c}\text { cRP, MPo, ctnl, Myo, cK-MB, } \\
\text { d-dimer, apoa1, apoB, BnP, } \\
\text { nt-proBnP, scd40l, } \\
\text { McP-1, adiponectin }\end{array}$ & Cardiovascular disease (CVD) & $\begin{array}{l}\text { Programmable bio-nanochip } \\
\text { (P-BNC) system }\end{array}$ & [48] \\
\hline $\begin{array}{l}\text { cea, ca125, Her2-neu, Psa } \\
\text { (free and complexed) }\end{array}$ & Cancer & $\begin{array}{c}\text { Programmable bio-nanochip (P-BNC) } \\
\text { system, 2D nanomaterials }\end{array}$ & {$[48,49]$} \\
\hline
\end{tabular}

\section{Point-of-Care Technology: An Overview}

Point-of-care $(\mathrm{PoC})$ technology in diagnostics tends to evaluate biomarkers that are suggestive of underlying biological or physical characteristics of an individual. Therefore, biomarkers determine the risk and severity of the disease, as well as the individual's response to treatment [15]. In addition to it, diagnostic methodologies other than biomarkers also include biochip and biosensor systems. Biochip systems obtain the requisite volume of saliva for testing whereas the biosensor system is the analytical high-sensitive technology for the detection of biomarkers [50]. Accurate PoC diagnostics needs no pre-processing and screening for biomarker identification on top of it non-invasive testing, as seen in already-patented devices, such as for the detection of oral cancer known as the Oral Fluid NanoSensor Test (OFNASET), the detection of human papillomavirus (HPV) infection OraRisk HPV test, and the diagnosis of periodontal diseases PerioPath [51,52]. Moreover, measuring the molecular level biomarkers in the form of proteins, mRNA, DNA, electrolytes, and small molecules requires techniques of microfabrication, such as in the developed micro/nanoelectromechanical systems (MEMS/NEMS) [53], and current emerging technologies provide new avenues of PoC diagnostics in the variety of "lab-on-chip" techniques which integrates the complexities of lab procedures on a computer chip in the size of a device that, hence, gives an opportunity to detect and diagnose multiple diseases simultaneously with the help of biomarkers [54].

\subsection{Diagnostic Targets}

Salivary diagnostics needs appropriate identification and validation of biomarkers for the detection of diseases, and a biomarker is a quantifiable parameter that can interact physiologically and biochemically at a molecular or cellular level, which sequentially acts as an indicator of normal, pathological, and interventional behaviours of the body's response [55,56]. Biomarkers include several classes, such as proteins, DNA, RNA, metabolites, and microbes, so collectively these all are used for diagnosis of several diseases and are called a molecular signature [57].

\subsection{Diagnostic Toolboxes}

Major salivary diagnostic tool boxes include proteomes, metabolomes, genomes (transcriptome, epigenome), microbiomes, and immunologic categories. Table 2 shows the variety of methods used to analyse molecules for the investigation and validation of biomarkers. Proteomes make up the biological system and could be employed for the detection of diabetes, periodontitis, caries, cystic fibrosis, AIDS, OSCC, breast cancer, lung cancer, pancreatic cancer, Sjogren's syndrome, and many more through mass spectroscopy, 2D gel electrophoresis, ELISA and protein immunoblot techniques [58-61]. However, mRNA and DNA come under salivary transcriptomes and genomes, and their profiling through gene chip arrays, DNA hybridization, qPCR, and gel electrophoresis helps in the detection of OSCC, as conducted by Li et al. [62], and in Sjogren's syndrome, hepatitis, HIV, etc. The metabolic investigation, on the other hand, requires and uses gas chromatography mass spectrometry, nuclear magnetic resonance spectroscopy, and high-performance liquid chromatography [63] for the detection 
of diabetes, lung, pancreatic, breast cancers, and Sjogren's syndrome [64,65]. In the same way, the salivary microbiome and immnomics used different methods, as mentioned in the table for the detection of infectious diseases, HIV, hepatitis, malaria, dengue, Ebola virus, cytomegalovirus, herpes infection, and countless other diseases [66-68].

Table 2. Methods used for the evaluation of diagnostic toolboxes.

\begin{tabular}{|c|c|c|c|}
\hline Diagnostic Toolbox & Methods of Evaluation & Molecules to Be Analysed & References \\
\hline $\begin{array}{l}\text { Genomics (Transcriptomics } \\
\text { and Epigenomics) }\end{array}$ & $\begin{array}{l}\text { Gene chip arrays, DNA hybridization, } \\
\text { qPCR, and gel electrophoresis }\end{array}$ & DNA, RNA and mRNA & {$[70]$} \\
\hline Metabolomics & $\begin{array}{c}\text { Nuclear magnetic resonance } \\
\text { spectroscopy (NMR), gas } \\
\text { chromatography-mass spectrometry, } \\
\text { direct flow injection/liquid } \\
\text { chromatography-mass spectrometry, } \\
\text { inductively coupled plasma mass } \\
\text { spectrometry, and high-performance } \\
\text { liquid chromatography (HPLC), } \\
\text { capillary electrophoresis time of flight } \\
\text { mass spectroscopy }\end{array}$ & $\begin{array}{l}\text { Small molecules end products of } \\
\text { metabolic processes in the body such as } \\
\text { organic species, together with } \\
\text { non-protein hormones (epinephrine, } \\
\text { peptide hormones and cortisol). }\end{array}$ & {$[71]$} \\
\hline Immunomics & Immunologic analysis & $\begin{array}{c}\text { Immunological markers (IgM, IgA, } \\
\text { and } \operatorname{IgG} \text { tests, and hepatitis B virus } \\
\text { and hepatitis } C \text { virus, } \operatorname{IgG})\end{array}$ & [67] \\
\hline
\end{tabular}

\subsection{Salivary Biomarker-Based PoC Platforms}

In Table 3, shows analysis system based on different technologies applied on saliva for the detection of biomarkers to reduce the time duration and early diagnosis of certain diseases. As shown in table it is revealed that single and multiplexed systems were being used such as MEMS, ORI, chromatography test strips and several salivary diagnostics devices (USA) for the detection of proteins solely, also proteins and nucleic acids altogether (for e.g., IL-8, MMP-8, a-amylase, HIV, HCV) with lowering the time limit as much little as one minute. These technologies, therefore, reduces the invasive procedures significantly to a larger level [16].

Table 3. Examples of single and multiplexed salivary biomarker-based PoC diagnostics [9].

\begin{tabular}{ccccc}
\hline PoC Platforms & System Used & Biomarker & Test Duration & Region of Origin \\
\hline \multirow{2}{*}{ Single } & $\begin{array}{c}\text { Microelectromechanical } \\
\text { technology (MEMS), optical } \\
\text { fluorescent system followed } \\
\text { by electrophoresis }\end{array}$ & Matrix metalloproteinase-8 MMP & 10 min & $\begin{array}{c}\text { Sandia National Lab } \\
\text { (USA) }\end{array}$ \\
\cline { 2 - 6 } & Oral risk indicator ORI & MMP-8 & Less than 10 min & Dentognostics (Germany) \\
\cline { 2 - 5 } & Chromatography test strips & HIV1\&2, HCV, influenza & 20 min & Orasure \\
\cline { 2 - 6 } & Handheld device & Cortisol, a-amylase & 1 min & Nipro (Japan) \\
\cline { 2 - 5 } Multiplexed & Salivary diagnostics & Salivary proteins and nucleic acids & Less than 15 min & SDx (USA) \\
\hline
\end{tabular}




\section{Emerging Novel PoC Technologies}

\subsection{Biosensors}

The biosensor is a bioanalytical device which has the ability to mimic any biological material, i.e., antibodies/antigens, nucleic acids, cellular structures or enzymes. That organic material is integrated into a transducing microsystem. The transducer could be electrochemical, thermometric, optical, piezoelectric, or magnetic, and this is called label-free detection [74], while label-based detection includes fluorescent immunoassays, FRET, and quantum dots. Biosensors function with the biorecognition of particular elements for particular targeted analytes and the maintenance of selectivity and sensitivity in the existence of other interfering compounds [75]. In the medical field, biosensor applications are growing rapidly, such as for the diagnosis of diabetes mellitus, urinary tract infections (UTI), identification of end-stage heart failure, and acute leukaemias (Table 1) [76].

\subsection{Fluorescent Biosensors}

Fluorescent biosensors can be used for cancer, drug discovery, arthritis, cardiovascular and neurodegenerative diseases, viral infections, chronic myeloid leukemia, and many more, by using the principal of high throughput screening approaches, the use of fluorescent probes in gene expression, localization of protein in cell cycle, apoptosis, signal transduction, and transcription. For the detection of chronic myeloid leukaemia, a genetically-encoded FRET biosensor was developed to detect Bcr-Abl kinase activity to see the correlation, it was further used to check the response to treatment, drug resistance, and predictive values for alternative therapeutics [77]. Moreover, Lee et al. applied hafnium oxide in a novel biosensor for the detection of human interleukin (IL-10) (atomic layer deposited hafnium oxide gate dielectrics for charge-based biosensors) [78]. Applications of nanomaterial biosensors give opportunities for a new generation of biosensor technologies that can be broadly used in monitoring, diagnosis, control, and analysis.

\subsection{Biological Micro-Electro-Mechanical Systems (BioMEMS)}

PoC lab-on-chip systems use small and simply-constructed (BioMEMS) devices for the detection of biological and chemical agents. BioMEMS are utilized for the detection of cells, proteins, microorganisms, viruses, and DNA in biological samples. They are based on micro/nanoscale fabrication systems which help in increasing the sensitivity of results from sensors, increased reliability, increased performance, reduced detection time, and cost effectiveness. It has label-free detection techniques, including micro-cantilevers, surface plasmon resonance (SPR), quartz crystal microbalances (QCM), and organic field-effect transistors (BioFETs) [79]. BioMEMS are used for a range of applications, such as for drug delivery, cardio MEMS to monitor heart patients, hearing aids, insulin micropumps, endoscopic pills, and retinal prosthesis [80,81] (Table 3). By blending molecular biology with computational systems, the major nanotechnology achievement could be bio-nano-electro-mechanical systems (BioNEMS) in the future for further improvements in the medical sector.

\subsection{Microfluidics/Paper-Based Technology}

Microfluidic applications operate on integrated microfabrication and specific physiochemical properties. Initially, the use of silicon, inorganic glass, and ceramic was used in microfluidic devices which have been vastly replaced by the soft and rigid thermostatic and thermoplastic materials and, finally, into paper-based technologies, using biodegradable and hydrogel materials [82]. At Harvard University in 2007 microfluidic paper-based analytical devices ( $\mu$ PADs) were pioneered by Whitesides. Paper is porous and hydrophilic, therefore, it provides a platform for the fabrication of microfluidic channels by patterning the paper with $2 \mathrm{D}$ and $3 \mathrm{D} \mu \mathrm{PADs}$ and having a variety of assay designs. They are used in the detection of urine metabolites, blood glucose, $\mathrm{pH}$ value, liver function, and infectious agents, and they are also widely used in pregnancy test kits [83]. 


\subsection{Electric Field-Induced Release and Measurement (EFIRM)}

A liquid biopsy technique called EFIRM, uses readout enzymes and immobilised probes for the capturing and detection of biomarkers from biofluids. EFIRM uses the electrochemical method to facilitate nucleic acid hybridization. This approach is advantageous for accurate detection of RNA, protein biomarker targets in exosomes. Additionally, without the extraction of DNA and nucleic acid, EFIRM can analyse the mutation status within an hour. IL-8 protein and IL-8 mRNA markers for oral cancer, non-squamous cell lung cancer (NSCLC) oncogenic mutation, and epidermal growth factor receptor (EGFR) mutation in non-small cell lung cancer can be detected through this EFIRM system $[57,84]$.

\subsection{Smartphone-Based Biosensors}

Smartphones operate similarly to miniature computers, acting as cheap, portable analytical laboratory devices. They are helpful for the detection, and diagnosis, of various diseases, such as cancer, tuberculosis, and the self-monitoring of blood glucose. Figure 2 illustrates the few shapes and designs of currently-used PoC technologies while Table 4 shows all the functions, techniques, and clinical utilities of these techniques in a concise manner.

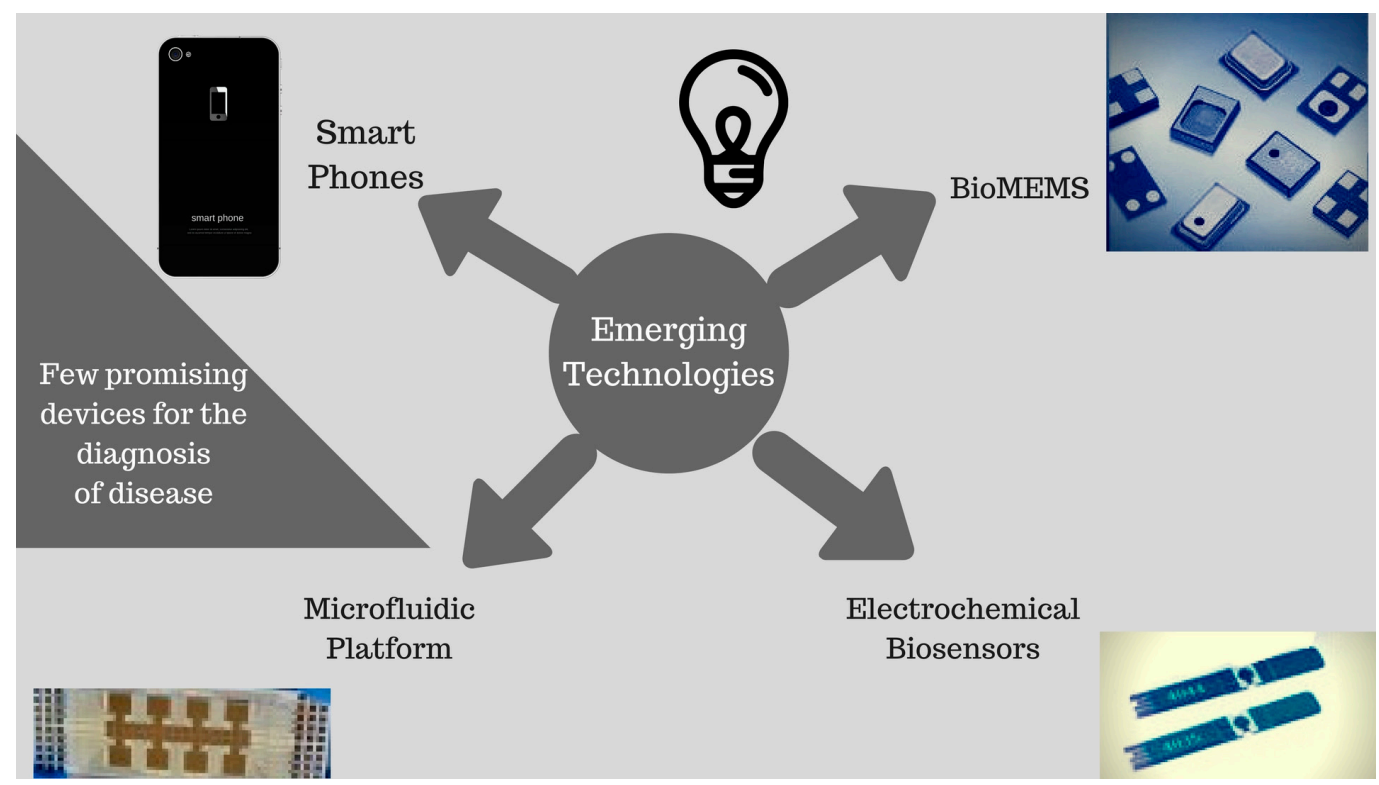

Figure 2. Illustration of a range of promising emerging methods of $\mathrm{PoC}$ technologies.

Recent advancements in smartphones electronics and new app development have made its use as a smart detector by having all the mixed optical methods, i.e., fluorescence, surface plasmon resonance (SPR), reflectance, absorbance, bio-chemiluminescence, and electrochemiluminescence [85]. Amongst them all SPR gained importance because of its high sensitivity, label-free, microfluidic technique. Conventional SPR utilizes planar thin gold film while localized SPR (LSPR) contains metal nanostructures [86]. Hence, SPR becomes the powerful tool in biomedical application such as for the study of several DNA, RNA, proteins, lipids, carbohydrates, even mutation detection [87]. Moreover, Lee et al. described the smartphone's function as a compact microscope in which ambient illumination as a light source was being used instead of a chip-scale method. This lensless imaging scheme allows sub-micron resolution and the built-in android application brings simplicity, robustness, and employability for several field applications [88]. 
Table 4. Variety of emerging PoC technologies and their clinical utility and functions.

\begin{tabular}{|c|c|c|c|c|}
\hline Types of Emerging Technologies & Biomarkers/Clinical Utility & Technique Used & Function & References \\
\hline Biosensors & $\begin{array}{l}\text { Diabetes mellitus, (glucose } \\
\text { biosensors), UTI, cardiac } \\
\text { markers, acute leukaemias }\end{array}$ & Electrochemical & $\begin{array}{l}\text { Drug delivery, cardio MEMS } \\
\text { to monitor heart patients, } \\
\text { hearing aids, insulin } \\
\text { micropumps, endoscopic pills, } \\
\text { retinal prosthesis }\end{array}$ & [79] \\
\hline $\begin{array}{l}\text { Fluorescent biosensors/ } \\
\text { FRET biosensor }\end{array}$ & $\begin{array}{l}\text { Drug discovery, arthritis, } \\
\text { cancers, cardiovascular and } \\
\text { neurodegenerative diseases, } \\
\text { viral infections, chronic } \\
\text { myeloid leukaemia }\end{array}$ & $\begin{array}{l}\text { Fluorescent probes are } \\
\text { mounted through a receptor }\end{array}$ & $\begin{array}{l}\text { They are able to probe gene } \\
\text { expression, localisation of } \\
\text { protein, signal transduction, } \\
\text { transcription and cell } \\
\text { cycle apoptosis }\end{array}$ & [77] \\
\hline $\begin{array}{l}\text { Biological Microelectromechanical } \\
\text { Systems (BioMEMS) }\end{array}$ & $\begin{array}{l}\text { Drug delivery, cardio MEMS, } \\
\text { insulin micro pumps, } \\
\text { endoscopic pills, } \\
\text { retinal prosthesis }\end{array}$ & $\begin{array}{l}\text { lab-on-a-chip systems /micro/ } \\
\text { nano-scale fabrication }\end{array}$ & $\begin{array}{l}\text { Detection of, proteins, viruses, } \\
\text { DNA and microorganisms }\end{array}$ & {$[80,81]$} \\
\hline $\begin{array}{l}\text { Microfluidics/paper } \\
\text { based technology }\end{array}$ & $\begin{array}{l}\text { Stomach cancer biomarkers } \\
\text { (H. pylori), detection of urine } \\
\text { metabolites, blood glucose, } \\
\text { pH value, liver function, } \\
\text { infectious agents }\end{array}$ & $\begin{array}{l}\text { Optoelectronic and } \\
\text { microfluidic system }\end{array}$ & $\begin{array}{l}\text { DNA extraction, } \\
\text { polymerase chain reaction } \\
\text { (PCR) amplification }\end{array}$ & [83] \\
\hline $\begin{array}{l}\text { Electric field induced release and } \\
\text { measurement EFIRM }\end{array}$ & $\begin{array}{l}\text { IL-8 protein and IL-8 mRNA } \\
\text { markers for oral cancer, } \\
\text { non-squamous cell lung } \\
\text { cancer (NSCLC) oncogenic } \\
\text { mutation, EGFR mutation in } \\
\text { no small cell lung cancer }\end{array}$ & Electrochemical & $\begin{array}{l}\text { Liquid biopsy technique, } \\
\text { selective hybridization }\end{array}$ & {$[57,84]$} \\
\hline Smartphone based biosensors & $\begin{array}{l}\text { Blood samples of falciparum } \\
\text { malaria infected and } \\
\text { fluorescent images } M \text {. } \\
\text { tuberculosis-positive sputum } \\
\text { smears, self-monitoring of } \\
\text { blood glucose, cancer }\end{array}$ & $\begin{array}{l}\text { Metal-oxide semiconductor } \\
\text { (CMOS)-based photo cameras, } \\
\text { optical-based methods } \\
\text { including absorbance, } \\
\text { chemiluminescence, } \\
\text { fluorescence, reflectance, } \\
\text { surface plasmon resonance } \\
\text { (SPR), bio- and } \\
\text { electrochemilumines-cence }\end{array}$ & $\begin{array}{l}\text { Detector system for } \\
\text { reflectance, colorimetry } \\
\text { and luminescence }\end{array}$ & [85] \\
\hline
\end{tabular}

\section{Future Direction and Conclusions}

This article gives an overview of research in molecular diagnostics, microbiology, and immunology. Routine laboratory testing includes the majority of haematology testing, clinical chemistry, and immunochemistry by using high-throughput instrumentation. Therefore, salivary PoCT diagnostics is replacing the central laboratory and offers efficient, fast, quick and easy automation. Since the emphasis is switching more towards prevention and early detection of a variety of diseases, development of small wireless devices has made a dramatic impact on healthcare services. The next decade will bring breakthroughs in terms of precision, efficiency, and bedside monitoring instead of hospital setups.

Personalised medicine, with the help of biosensors, lab-on-chip systems, individual genetics, smartphones monitoring parameters, and microfluidic devices, will improve the primary healthcare system. Moreover, it allows clinicians to be accurate, to be more consistent, to capture clinical data quickly, provide patient satisfaction, and streamline workflow. Salivary diagnostics' impact on the healthcare system is enormous, being non-invasive, convenient, and well-credentialed, while bioinformatics introduction will make standards and performance higher and improved.

Acknowledgments: We are thankful to Pakistan Human Saliva Research Group (PHSRG) for helping us with the write-up and compilation of all knowledge on one platform.

Author Contributions: Rabia Sannam Khan brought the idea of this innovative topic and helped in whole paper write-up. Zohaib Khurshid and Faris Yahya Ibrahim Asiri supported in the compilation of tables, figures and English improvement.

Conflicts of Interest: The authors declare no conflict of interest.

\section{References}

1. St John, A.; Price, C.P. Existing and emerging technologies for point-of-care testing. Clin. Biochem. Rev. Aust. Assoc. Clin. Biochem. 2014, 35, 155-167. 
2. Jani, I.V.; Peter, T.F. How point-of-care testing could drive innovation in global health. New Engl. J. Med. 2013, 368, 2319-2324. [CrossRef] [PubMed]

3. Shetty, V.; Yamaguchi, M. Salivary biosensors for screening trauma-related psychopathology. Oral Maxillofac. Surg. Clin. North Am. 2010, 22, 269-278. [CrossRef] [PubMed]

4. Khanna, P.; Walt, D.R. Salivary diagnostics using a portable point-of-service platform: A review. Clin. Ther. 2015, 37, 498-504. [CrossRef] [PubMed]

5. Khurshid, Z.; Zohaib, S.; Najeeb, S.; Zafar, M.; Rehman, R.; Rehman, I. Advances of proteomic sciences in dentistry. Int. J. Mol. Sci. 2016, 17, 728. [CrossRef] [PubMed]

6. Sahibzada, H.A.; Khurshid, Z.; Khan, R.S.; Naseem, M.; Siddique, K.M.; Mali, M.; Zafar, M.S. Salivary IL-8, IL-6 and TNF- $\alpha$ as potential diagnostic biomarkers for oral cancer. Diagnostics 2017, 7, 21. [CrossRef] [PubMed]

7. Sannam Khan, R.; Khurshid, Z.; Akhbar, S.; Faraz Moin, S. Advances of salivary proteomics in oral squamous cell carcinoma (OSCC) detection: An update. Proteomes 2016, 4, 41. [CrossRef] [PubMed]

8. Khurshid, Z.; Najeeb, S.; Mali, M.; Moin, S.F.; Raza, S.Q.; Zohaib, S.; Sefat, F.; Zafar, M.S. Histatin peptides: Pharmacological functions and their applications in dentistry. Saudi Pharm. J. 2015, 25, 25-31. [CrossRef] [PubMed]

9. Khurshid, Z.; Mali, M.; Naseem, M.; Najeeb, S.; Zafar, M. Human gingival crevicular fluids (GCF) proteomics: An overview. Dent. J. 2017, 5, 12. [CrossRef]

10. Khurshid, Z.; Haq, J.A.; Khan, R.S.; Sohail Zafar, M.; Altaf, M.; Najeeb, S. Human saliva and its role in oral \& systemic health. J. Pak. Dent. Assoc. 2016, 25, 170-174.

11. Khurshid, Z.; Naseem, M.; Sheikh, Z.; Najeeb, S.; Shahab, S.; Zafar, M.S. Oral antimicrobial peptides: Types and role in the oral cavity. Saudi Pharm. J. 2015, 24, 515-524. [CrossRef] [PubMed]

12. Khurshid, Z.; Zohaib, S.; Najeeb, S.; Zafar, M.; Slowey, P.; Almas, K. Human saliva collection devices for proteomics: An update. Int. J. Mol. Sci. 2016, 17, 846. [CrossRef] [PubMed]

13. Tabak, L.A. In defense of the oral cavity: The protective role of the salivary secretions. Pediatr. Dent. 2006, 28, 110-198. [PubMed]

14. Tsuchida, S.; Satoh, M.; Sogawa, K.; Kawashima, Y.; Kado, S.; Ishige, T.; Beppu, M.; Sawai, S.; Nishimura, M.; Kodera, Y.; et al. Application of proteomic technologies to discover and identify biomarkers for periodontal diseases in gingival crevicular fluid: A review. Proteom. Clin. App. 2014, 8, 232-240. [CrossRef]

15. Tabak, L.A. Point-of-care diagnostics enter the mouth. Ann. N. Y. Acad. Sci. 2007, 1098, 7-14. [CrossRef] [PubMed]

16. Wei, F.; Wong, D.T.W. Point-of-care platforms for salivary diagnostics. Chin. J. Dent. Res. 2012, 15, 7-15. [PubMed]

17. Slomiany, B.L.; Murty, V.L.N.; Slomiany, A. Salivary lipids in health and disease. Prog. Lipid Res. 1985, 24, 311-324. [CrossRef]

18. Actis, A.B.; Perovic, N.R.; Defagó, D.; Beccacece, C.; Eynard, A.R. Fatty acid profile of human saliva: A possible indicator of dietary fat intake. Arch. Oral Biol. 2005, 50, 1-6. [CrossRef] [PubMed]

19. Javaid, M.A.; Ahmed, A.S.; Durand, R.; Tran, S.D. Saliva as a diagnostic tool for oral and systemic diseases. J. Oral Biol. Craniofac. Res. 2016, 6, 67-76. [CrossRef] [PubMed]

20. Deutsch, O.; Krief, G.; Konttinen, Y.T.; Zaks, B.; Wong, D.T.; Aframian, D.J.; Palmon, A. Identification of Sjogren's syndrome oral fluid biomarker candidates following high-abundance protein depletion. Rheumatology 2015, 54, 884-890. [CrossRef] [PubMed]

21. Delaleu, N.; Mydel, P.; Kwee, I.; Brun, J.G.; Jonsson, M.V.; Jonsson, R. High fidelity between saliva proteomics and the biologic state of salivary glands defines biomarker signatures for primary Sjgren's syndrome. Arthritis Rheumatol. 2015, 67, 1084-1095. [CrossRef] [PubMed]

22. Langie, S.A.S.; Szarc Vel Szic, K.; Declerck, K.; Traen, S.; Koppen, G.; Van Camp, G.; Schoeters, G.; Vanden Berghe, W.; De Boever, P. Whole-genome saliva and blood DNA methylation profiling in individuals with a respiratory allergy. PLoS ONE 2016, 11, e0151109. [CrossRef] [PubMed]

23. Maria, N.I.; Brkic, Z.; Waris, M.; van Helden-Meeuwsen, C.G.; Heezen, K.; van de Merwe, J.P.; van Daele, P.L.; Dalm, V.A.S.H.; Drexhage, H.A.; Versnel, M.A. MxA as a clinically applicable biomarker for identifying systemic interferon type I in primary Sjogren's syndrome. Ann. Rheum. Dis. 2014, 73, 1052-1059. [CrossRef] [PubMed] 
24. Kramer, J.M.; Klimatcheva, E.; Rothstein, T.L. CXCL13 is elevated in Sjogren's syndrome in mice and humans and is implicated in disease pathogenesis. J. Leukoc. Biol. 2013, 94, 1079-1089. [CrossRef] [PubMed]

25. Lee, H.T.; Shiao, Y.M.; Wu, T.H.; Chen, W.S.; Hsu, Y.H.; Tsai, S.F.; Tsai, C.Y. Serum BLC/CXCL13 concentrations and renal expression of CXCL13/CXCR5 in patients with systemic lupus erythematosus and lupus nephritis. J. Rheum. 2010, 37, 45-52. [CrossRef] [PubMed]

26. Out, D.; Hall, R.J.; Granger, D.A.; Page, G.G.; Woods, S.J. Assessing salivary C-reactive protein: Longitudinal associations with systemic inflammation and cardiovascular disease risk in women exposed to intimate partner violence. Brain Behav. Immun. 2012, 26, 543-551. [CrossRef] [PubMed]

27. Mirzaii-Dizgah, I.; Riahi, E. Salivary high-sensitivity cardiac troponin T levels in patients with acute myocardial infarction. Oral Dis. 2013, 19, 180-184. [CrossRef] [PubMed]

28. Mirzaii-Dizgah, I.; Jafari-Sabet, M. Unstimulated whole saliva creatine phosphokinase in acute myocardial infarction. Oral Dis. 2011, 17, 597-600. [CrossRef] [PubMed]

29. Foo, J.Y.Y.; Wan, Y.; Kostner, K.; Arivalagan, A.; Atherton, J.; Cooper-White, J.; Dimeski, G.; Punyadeera, C. NT-ProBNP levels in saliva and its clinical relevance to heart failure. PLoS ONE 2012, 7, e48452. [CrossRef] [PubMed]

30. Chee, C.S.; Chang, K.M.; Loke, M.F.; Angela Loo, V.P.; Subrayan, V. Association of potential salivary biomarkers with diabetic retinopathy and its severity in type-2 diabetes mellitus: A proteomic analysis by mass spectrometry. PeerJ 2016, 4, e2022. [CrossRef] [PubMed]

31. Zhang, C.Z.; Cheng, X.Q.; Li, J.Y.; Zhang, P.; Yi, P.; Xu, X.; Zhou, X.D. Saliva in the diagnosis of diseases. Int. J. Oral Sci. 2016. [CrossRef] [PubMed]

32. Ladgotra, A. Estimation of salivary and serum biomarkers in diabetic and non diabetic patients-A comparative study. J. Clin. Diagn. Res. 2016, 10, ZC56-ZC61. [CrossRef] [PubMed]

33. Shetty, V.; Zigler, C.; Robles, T.F.; Elashoff, D.; Yamaguchi, M. Developmental validation of a point-of-care, salivary? Amylase biosensor. Psychoneuroendocrinology 2011, 36, 193-199. [CrossRef] [PubMed]

34. Gaydos, C.A.; Solis, M.; Hsieh, Y.H.; Jett-Goheen, M.; Nour, S.; Rothman, R.E. Use of tablet-based kiosks in the emergency department to guide patient HIV self-testing with a point-of-care oral fluid test. Int. J. STD AIDS 2013, 24, 716-721. [CrossRef] [PubMed]

35. Zachary, D.; Mwenge, L.; Muyoyeta, M.; Shanaube, K.; Schaap, A.; Bond, V.; Kosloff, B.; de Haas, P.; Ayles, H. Field comparison of oraquick advance rapid HIV-1/2 antibody test and two blood-based rapid HIV antibody tests in Zambia. BMC Infect. Dis. 2012, 12, 183. [CrossRef] [PubMed]

36. Tucker, J.D.; Bien, C.H.; Peeling, R.W. Point-of-care testing for sexually transmitted infections: Recent advances and implications for disease control. Curr. Opin. Infect. Dis. 2013, 26, 73-79. [CrossRef] [PubMed]

37. Teengam, P.; Siangproh, W.; Tuantranont, A.; Vilaivan, T.; Chailapakul, O.; Henry, C.S. Multiplex paper-based colorimetric DNA sensor using pyrrolidinyl peptide nucleic acid-induced AgNPs aggregation for detecting MERS-CoV, MTB, and HPV oligonucleotides. Anal. Chem. 2017, 89, 5428-5435. [CrossRef] [PubMed]

38. Tlili, C.; Myung, N.V.; Shetty, V.; Mulchandani, A. Label-free, chemiresistor immunosensor for stress biomarker cortisol in saliva. Biosens. Bioelectron. 2011, 26, 4382-4386. [CrossRef] [PubMed]

39. Ji, S.; Choi, Y. Point-of-care diagnosis of periodontitis using saliva: Technically feasible but still a challenge. Front. Cell. Infect. Microbiol. 2015, 5, 1-9. [CrossRef] [PubMed]

40. Floriano, P.N.; Christodoulides, N.; Miller, C.S.; Ebersole, J.L.; Spertus, J.; Rose, B.G.; Kinane, D.F.; Novak, M.J.; Steinhubl, S.; Acosta, S.; et al. Use of saliva-based nano-biochip tests for acute myocardial infarction at the point of care: A feasibility study. Clin. Chem. 2009, 55, 1530-1538. [CrossRef] [PubMed]

41. Blicharz, T.M.; Siqueira, W.L.; Helmerhorst, E.J.; Oppenheim, F.G.; Wexler, P.J.; Little, F.F.; Walt, D.R. Fiber-optic microsphere-based antibody array for the analysis of inflammatory cytokines in saliva. Anal. Chem. 2009, 81, 2106-2114. [CrossRef] [PubMed]

42. Torrente-Rodrguez, R.M.; Campuzano, S.; Ruiz-Valdepeas Montiel, V.; Gamella, M.; Pingarrn, J.M. Electrochemical bioplatforms for the simultaneous determination of interleukin (IL)-8 mRNA and IL-8 protein oral cancer biomarkers in raw saliva. Biosens. Bioelectron. 2016, 77, 543-548. [CrossRef] [PubMed]

43. Walt, D.R.; Blicharz, T.M.; Hayman, R.B.; Rissin, D.M.; Bowden, M.; Siqueira, W.L.; Helmerhorst, E.J.; Grand-Pierre, N.; Oppenheim, F.G.; Bhatia, J.S.; et al. Microsensor arrays for saliva diagnostics. Ann. N. Y. Acad. Sci. 2007, 1098, 389-400. [CrossRef] [PubMed] 
44. Barnfather, K.D.; Cope, G.F.; Chapple, I.L. Effect of incorporating a $10 \mathrm{~min}$ point of care test for salivary nicotine metabolites into a general practice based smoking cessation programme: Randomised controlled trial. BMJ Clin. Res. 2005, 331, 999. [CrossRef] [PubMed]

45. Ching, K.H.; Burbelo, P.D.; Gonzalez-Begne, M.; Roberts, M.E.P.; Coca, A.; Sanz, I.; Iadarola, M.J. Salivary anti-Ro60 and anti-Ro52 antibody profiles to diagnose Sjogren's Syndrome. J. Dent. Res. 2011, 90, 445-449. [CrossRef] [PubMed]

46. Du, Y.; Zhang, W.; Wang, M.L. Sensing of salivary glucose using nano-structured biosensors. Biosensors 2016, 6, 10. [CrossRef] [PubMed]

47. Zhang, W.; Du, Y.; Wang, M.L. Noninvasive glucose monitoring using saliva nano-biosensor. Sens. BioSens. Res. 2015, 4, 23-29. [CrossRef]

48. Christodoulides, N.; Pierre, F.N.; Sanchez, X.; Li, L.; Hocquard, K.; Patton, A.; Muldoon, R.; Miller, C.S.; Ebersole, J.L.; Redding, S.; et al. Programmable bio-nanochip technology for the diagnosis of cardiovascular disease at the point-of-care. Methodist DeBakey Cardiovasc. J. 2012, 8, 6-12. [CrossRef] [PubMed]

49. Wang, L.; Xiong, Q.; Xiao, F.; Duan, H. 2D nanomaterials based electrochemical biosensors for cancer diagnosis. Biosens. Bioelectron. 2017, 89, 136-151. [CrossRef] [PubMed]

50. Yamaguchi, M. Salivary sensors in point-of-care testing. Sens. Mater. 2010, 22, 143-153.

51. Cone, E.J.; Clarke, J.; Tsanaclis, L. Prevalence and disposition of drugs of abuse and opioid treatment drugs in oral fluid. J. Anal. Toxicol. 2007, 31, 424-433. [CrossRef] [PubMed]

52. Gau, V.; Wong, D. Oral fluid nanosensor test (OFNASET) with advanced electrochemical-based molecular analysis platform. Ann. N. Y. Acad. Sci. 2007, 1098, 401-410. [CrossRef] [PubMed]

53. Kaczor-Urbanowicz, K.E.; Martin Carreras-Presas, C.; Aro, K.; Tu, M.; Garcia-Godoy, F.; Wong, D.T. Saliva diagnostics-Current views and directions. Exp. Biol. Med. 2016, 242, 459-472. [CrossRef] [PubMed]

54. Chin, C.D.; Linder, V.; Sia, S.K.; Daar, A.S.; Thorsteinsdottir, H.; Martin, D.K. Lab-on-a-chip devices for global health: Past studies and future opportunities. Lab Chip 2007, 7, 41-57. [CrossRef] [PubMed]

55. Silberring, J.; Ciborowski, P. Biomarker discovery and clinical proteomics. Trends Anal. Chem. 2010, 29, 128-140. [CrossRef] [PubMed]

56. Ilyin, S.E.; Belkowski, S.M.; Plata-Salamán, C.R. Biomarker discovery and validation: Technologies and integrative approaches. Trends Biotechnol. 2004, 22, 411-416. [CrossRef] [PubMed]

57. Wang, A.; Wang, C.; Tu, M.; Wong, D. Oral biofluid biomarker research: Current status and emerging frontiers. Diagnostics 2016, 6, 45. [CrossRef] [PubMed]

58. St. John, M.A.R.; Li, Y.; Zhou, X.; Denny, P.; Ho, C.M.C.M.; Montemagno, C.; Shi, W.; Qi, F.; Wu, B.; Sinha, U.; et al. Interleukin 6 and interleukin 8 as potential biomarkers for oral cavity and oropharyngeal squamous cell carcinoma. Arch. Otolaryngol. Head Neck Surg. 2004, 130, 929-935. [CrossRef] [PubMed]

59. Landrum, M.L.; Wilson, C.H.; Perri, L.P.; Hannibal, S.L.; O'Connell, R.J. Usefulness of a rapid human immunodeficiency virus-1 antibody test for the management of occupational exposure to blood and body fluid. Infect. Control Hosp. Epidemiol. 2005, 26, 768-774. [CrossRef] [PubMed]

60. Genco, R.J.; Grossi, S.G.; Ho, A.; Nishimura, F.; Murayama, Y. A proposed model linking inflammation to obesity, diabetes, and periodontal infections. J. Periodontol. 2005, 76, 2075-2084. [CrossRef] [PubMed]

61. Huang, C.M. Comparative proteomic analysis of human whole saliva. Arch. Oral Biol. 2004, 49, $951-962$. [CrossRef] [PubMed]

62. Li, Y.; St. John, M.A.R.; Zhou, X.; Kim, Y.; Sinha, U.; Jordan, R.C.K.; Eisele, D.; Abemayor, E.; Elashoff, D.; Park, N.H.; et al. Salivary transcriptome diagnostics for oral cancer detection. Clin. Cancer Res. 2004, 10, 8442-8450. [CrossRef] [PubMed]

63. Roberts, L.D.; Souza, A.L.; Gerszten, R.E.; Clish, C.B. Targeted metabolomics. Curr. Protoc. Mol. Biol. 2012. [CrossRef]

64. Kageyama, G.; Saegusa, J.; Irino, Y.; Tanaka, S.; Tsuda, K.; Takahashi, S.; Sendo, S.; Morinobu, A. Metabolomics analysis of saliva from patients with primary Sjgren's syndrome. Clin. Exp. Immunol. 2015, 182, 149-153. [CrossRef] [PubMed]

65. Sugimoto, M.; Wong, D.T.; Hirayama, A.; Soga, T.; Tomita, M. Capillary electrophoresis mass spectrometry-based saliva metabolomics identified oral, breast and pancreatic cancer-specific profiles. Metabolomics 2010, 6, 78-95. [CrossRef] [PubMed]

66. Wang, C.; Li, J. Pathogenic microorganisms and pancreatic cancer. Gastrointest. Tumors 2015, 2, 41-47. [CrossRef] [PubMed] 
67. Hu, S.; Vissink, A.; Arellano, M.; Roozendaal, C.; Zhou, H.; Kallenberg, C.G.; Wong, D.T. Identification of autoantibody biomarkers for primary Sjogren's syndrome using protein microarrays. Proteomics 2011, 11, 1499-1507. [CrossRef] [PubMed]

68. Sakamoto, M.; Umeda, M.; Benno, Y. Molecular analysis of human oral microbiota. J. Periodontal Res. 2005, 40, 277-285. [CrossRef] [PubMed]

69. Zhang, L.; Xiao, H.; Karlan, S.; Zhou, H.; Gross, J.; Elashoff, D.; Akin, D.; Yan, X.; Chia, D.; Karlan, B.; et al. Discovery and preclinical validation of salivary transcriptomic and proteomic biomarkers for the non-invasive detection of breast cancer. PLoS ONE 2010, 5, e15573. [CrossRef] [PubMed]

70. Hu, Z.; Zimmermann, B.G.; Zhou, H.; Wang, J.; Henson, B.S.; Yu, W.; Elashoff, D.; Krupp, G.; Wong, D.T. Exon-level expression profiling: A comprehensive transcriptome analysis of oral fluids. Clin. Chem. 2008, 54, 824-832. [CrossRef] [PubMed]

71. Idle, J.R.; Gonzalez, F.J. Metabolomics. Cell Metab. 2007, 6, 348-351. [CrossRef] [PubMed]

72. Chen, L.; Liu, F.; Fan, X.; Gao, J.; Chen, N.; Wong, T.; Wu, J.; Wen, S.W. Detection of hepatitis B surface antigen, hepatitis B core antigen, and hepatitis B virus DNA in parotid tissues. Int. J. Infect. Dis. 2009, 13, 20-23. [CrossRef] [PubMed]

73. Nasidze, I.; Quinque, D.; Li, J.; Li, M.; Tang, K.; Stoneking, M. Comparative analysis of human saliva microbiome diversity by barcoded pyrosequencing and cloning approaches. Anal. Biochem. 2009, 391, 64-68. [CrossRef] [PubMed]

74. Soper, S.A.; Brown, K.; Ellington, A.; Frazier, B.; Garcia-Manero, G.; Gau, V.; Gutman, S.I.; Hayes, D.F.; Korte, B.; Landers, J.L.; et al. Point-of-care biosensor systems for cancer diagnostics/prognostics. Biosens. Bioelectron. 2006, 21, 1932-1942. [CrossRef] [PubMed]

75. Collings, A.F.; Caruso, F. Biosensors: Recent advances. Rep. Prog. Phys. 1997, 60, 1397-1445. [CrossRef]

76. McRae, M.P.; Simmons, G.W.; Wong, J.; Shadfan, B.; Gopalkrishnan, S.; Christodoulides, N.; McDevitt, J.T. Programmable bio-nano-chip system: A flexible point-of-care platform for bioscience and clinical measurements. Lab Chip 2015, 15, 4020-4031. [CrossRef] [PubMed]

77. Mehrotra, P. Biosensors and their applications-A review. J. Oral Biol. Craniofac. Res. 2016, 6, 153-159. [CrossRef] [PubMed]

78. Lee, M.; Zine, N.; Baraket, A.; Zabala, M.; Campabadal, F.; Caruso, R.; Trivella, M.G.; Jaffrezic-Renault, N.; Errachid, A. A novel biosensor based on hafnium oxide: Application for early stage detection of human interleukin-10. Sens. Actuators B Chem. 2012, 175, 201-207. [CrossRef]

79. Vasan, A.S.S. Point-of-care biosensor system. Front. Biosci. 2013, S5, S357. [CrossRef]

80. Mastrangelo, C.H.; Burns, M.A.; Burke, D.T. Microfabricated devices for genetic diagnostics. Proc. IEEE 1998, 86, 1769-1786. [CrossRef]

81. Gilleo, K. MEMS in medicine. Circuits Assem. 2005, 16, 32-33.

82. Naher, S.; Orpen, D.; Brabazon, D.; Morshed, M.M. An overview of microfluidic mixing application. Adv. Mater. Res. 2009, 83-86, 931-939. [CrossRef]

83. Hu, J.; Wang, S.Q.; Wang, L.; Li, F.; Pingguan-Murphy, B.; Lu, T.J.; Xu, F. Advances in paper-based point-of-care diagnostics. Biosens. Bioelectron. 2014, 54, 585-597. [CrossRef] [PubMed]

84. Wei, F.; Yang, J.; Wong, D.T.W. Detection of exosomal biomarker by electric field-induced release and measurement (EFIRM). Biosens. Bioelectron. 2013, 44, 115-121. [CrossRef] [PubMed]

85. Roda, A.; Michelini, E.; Zangheri, M.; Di Fusco, M.; Calabria, D.; Simoni, P. Smartphone-based biosensors: A critical review and perspectives. Trends Anal. Chem. 2016, 79, 317-325. [CrossRef]

86. Wang, D.S.; Fan, S.K. Microfluidic surface plasmon resonance sensors: From principles to point-of-care applications. Sensors 2016, 16, 1175. [CrossRef] [PubMed]

87. Nguyen, H.H.; Park, J.; Kang, S.; Kim, M. Surface plasmon resonance: A versatile technique for biosensor applications. Sensors 2015, 15, 10481-10510. [CrossRef] [PubMed]

88. Lee, S.A.; Yang, C.A. Smartphone-based chip-scale microscope using ambient illumination. Lab Chip 2014, 14, 3056. [CrossRef] [PubMed]

(C) 2017 by the authors. Licensee MDPI, Basel, Switzerland. This article is an open access article distributed under the terms and conditions of the Creative Commons Attribution (CC BY) license (http:/ / creativecommons.org/licenses/by/4.0/). 